This is the Accepted Version of an article published online 28 June 2016 by Oxford University Press in London Review of International Law. Please refer to published version when citing, available at:

http://Iril.oxfordjournals.org/content/early/2016/06/27/Iril.Irw011.extract

Accepted Version Downloaded from SOAS Research Online: http://eprints.soas.ac.uk/22669/

Review of David Kennedy's, A World of Struggle: How Power, Law. and Experience Shape Global Political Economy

Stephen Hopgood, SOAS University of London (sh18@soas.ac.uk).

\title{
Law and Lawyers in a World After Virtue
}

David Kennedy has been one of the central figures in the discipline of Critical Legal Studies for almost four decades and for political scientists like me, who see the law as just another way of doing politics, a seminal figure in wresting monopolistic control over interpreting the law's purpose and meaning away from professional lawyers and legal scholars and into the realm where people are, to paraphrase Austin, 'doing things with words.' Pivotal to this contribution has been Kennedy's willingness to confront trade-offs, to see the darker underbelly of any pursuit of justice, moral, legal, social or otherwise, and yet to remain committed to the possibility of moving human affairs in a broadly progressive direction. He is an anti-utopian in this sense, an anti-sacralizer, a myth-buster, a realist but with an ethical core. The antinomies of modernity must be confronted but need not be ethically disabling. In some of his best known works, The Rights of Spring and The Dark Sides of Virtue, he has even drawn on and problematized his own experiences of being an expert legal scholar and, if not quite an activist, then certainly an engaged and concerned participant in the fields of human rights and humanitarian law. In A World of Struggle, he reflects more systematically on his many encounters with experts and expertise, including his own experiences at Davos. This distillation of experience and contemplation focuses on the question of what lies at the ethical heart of law and lawyering. This, as Kennedy shows at length, is the core of modernity's challenge.

Indeed, Max Weber haunts these pages. In many ways, Kennedy's account is an anthropology of the everyday impact of the very legal-rational dynamic of modernity that Weber so brilliantly described one hundred years ago: 
This is the Accepted Version of an article published online 28 June 2016 by Oxford University Press in London Review of International Law. Please refer to published version when citing, available at:

http://Iril.oxfordjournals.org/content/early/2016/06/27/Iril.Irw011.extract

Accepted Version Downloaded from SOAS Research Online: http://eprints.soas.ac.uk/22669/

The more complicated and specialized modern culture becomes, the more its external supporting apparatus demands the personally detached and strictly 'objective' expert, in lieu of the master of older social structures, who was moved by personal sympathy and favor, grace and gratitude. ${ }^{1}$

At the core of this shift, for Weber, was the move from God to science. That is, from a mostly subjective and ostensibly personal and idiosyncratic world where faith and fate played a central role to one of positivism, objective facts and statistical regularities, where traditional communities gave way to complex states with their extraordinary range of technological achievements. ${ }^{2}$ A shift from natural law to positive law, and from prophecy to policy. As Marx and Engels put it pithily, decades earlier: 'All that is solid melts into air, all that is holy is profaned. ${ }^{3}$

This transformation put under the microscope, often literally, the dying world of cosmic justice and divine intervention and replaced them with legal-rational authority exemplified in the figure of the state bureaucrat. ${ }^{4}$ We were no longer victims of destiny but were able to know, learn and most of all control natural and social, including economic, life. We could will the future. What followed was a growing belief in the power of rationality and efficiency in administration and law, with bureaucracy and capitalism finding common cause around quantification and calculable rules. This release from 'self-incurred tutelage,' as Kant put it, might have been unavoidable but it also meant something was lost and Weber memorably acknowledged what: 'The fate of our times is characterized by rationalization and

\footnotetext{
${ }^{1}$ H. H. Gerth and C. Wright Mills, From Max Weber: Essays in Sociology (London: Routledge and Kegan Paul, 1947), p. 216. Italics in original.

${ }^{2}$ The negative implications for morality and meaning of the turn to science would unite a group of thinkers including Alasdair Maclntyre and Leo Strauss with one of the doyens of the Critical Legal Studies movement, Roberto Unger; see Stephen Holmes, The Anatomy of Antiliberalism (Cambridge, MA: Harvard University Press, 1993). My title is taken, obviously, from Maclntyre's After Virtue: A Study in Moral Theory (Notre Dame: University of Notre Dame Press, 1981).

${ }^{3}$ Karl Marx and Friedrich Engels, The Communist Manifesto (1848), chap. 1.

${ }^{4}$ Weber is interesting on what he calls 'professional politicians' (among whom lawyers are prominent) who sound a lot like today's political apparatchiks, including such media experts as 'spin doctors' - the newest professional category of expert attaching itself nominally to one of the oldest: From Max Weber, pp. 82-85.
} 
This is the Accepted Version of an article published online 28 June 2016 by Oxford University Press in London Review of International Law. Please refer to published version when citing, available at:

http://Iril.oxfordjournals.org/content/early/2016/06/27/Iril.Irw011.extract

Accepted Version Downloaded from SOAS Research Online: http://eprints.soas.ac.uk/22669/

intellectualization and, above all, by the "disenchantment of the world"'5

We no longer believed in miracles and magic. The mystery was gone. We were human animals who held our destiny in our own hands, able now to create (e.g., penicillin) and destroy (e.g., nuclear power) on a vast scale. Our world was that of social and scientific engineering and at its heart, in the era of rationalized authority, where the now vanquished old Gods and kings once dwelt, sat perhaps the twentieth century's most important questions about legitimate rule: By whom, in whose name, by what right, and to what end? The decline in the power of traditional religious and political authorities democratized the sphere of rulership, a shift in which the United States was prominent. At the same time, advances in science and technology, always operating hand-in-hand with state bureaucracy and money, gave huge power to bureaucrats and capitalists to shape every aspect of contemporary life, from health to reproduction to mood to consumption.

Some feared that this new democratic mass would be cannon fodder for a rampant 'culture industry' that would turn them into zombies by feeding them the equivalent of intellectual valium. ${ }^{6}$ Some feared that the state's overweening power would herald totalitarianism, the Nazi and Soviet states being the prime examples, as exemplified by the 'banal' bureaucrat Adolf Eichmann complaining with apparent sincerity that he had been highly efficient at transporting Jews to their deaths and still he was overlooked for promotion by his SS superiors. ${ }^{7}$ Others identified the myriad ways that professional expertise exercised momentous power by producing the very subjects who were supposed to be acting and choosing in this brave new world. ${ }^{8}$ And yet there was a parallel and more influential strain of thought, most obviously in the newly ascendant United States, that saw great potential in

\footnotetext{
${ }^{5}$ Gerth and Mills, From Max Weber, p. 155. Weber's touchstone to avoid complete disorientation was his attachment to the nation; see Andreas Anter, Max Weber's Theory of the Modern State, trans. by Keith Tribe (London: Palgrave/Macmillan, 2014), pp. 124-133.

${ }^{6}$ Most obviously. Theodore W. Adorno and Max Horkheimer, Dialectic of Enlightenment (London: Verso, 1997). For more on the various sceptical analyses of modernity by non-Marxist 'antiliberals,' see Holmes, The Anatomy of Antiliberalism.

${ }^{7}$ Hannah Arendt, Eichmann in Jerusalem: A Report on the Banality of Evil (London: Penguin Books, 2006); Zygmunt Bauman, Modernity and the Holocaust (Cambridge: Polity Press, 2000).

${ }^{8}$ See e.g., Michael Foucault, The History of Sexuality 1: An Introduction (New York, Vintage/Random House 1990).
} 
This is the Accepted Version of an article published online 28 June 2016 by Oxford University Press in London Review of International Law. Please refer to published version when citing, available at:

http://Iril.oxfordjournals.org/content/early/2016/06/27/Iril.Irw011.extract

Accepted Version Downloaded from SOAS Research Online: http://eprints.soas.ac.uk/22669/

the rise of science, technology and rational democratic administration as long as the right people were in charge of the machine.

The modernization theorists believed that bureaucracies, technical experts, and social engineers of various stripes should impose economic and political order on cities, nations, and the world. Nazism, therefore, was not a manifestation of bureaucracy and social engineering gone mad, but rather an example of populism in power. The modernization theorists may have favored democracy, but only insofar as it involved a docile demos, firmly subordinated to "responsible" managers. Technocracy rather than "people's liberation" was what modernization would ideally achieve. Despite their statist proclivities, modernization theorists were thus in an important sense antipolitical: politics was the realm of subjective messiness rather than scientific exactitude. ${ }^{9}$

These were modern philosopher-kings, floating freely above the fray of politics with all its neediness, passion, emotion and self-interest, and putting the public's long-term interest first (whether that public would have thanked them for it or not). Elite rule was not to be feared but to be encouraged. The 1960s may have seen resistance from the new left determined to counter the culture of technocracy and expert rule, but it also brought to the fore some notable high priests of modern management techniques like Robert $\mathrm{S}$. McNamara, head of the Ford Motor Company, then architect of the Vietnam War. The Carter administration after 1977, wary of religious evangelism, would try to tackle this fear of moral disintegration in a disenchanted world with the idea of human rights, setting up a tension that is still with us between the political and moral demand for rights and their legalistic expression, between the why and the how. ${ }^{10}$

For technocrats, the question, to recall Harold Lasswell's description of politics, was about 'who got what, when and how.' In keeping with Weber, why was now off the table, foundational values were out, and technical efficiency was in. The burgeoning reach of

\footnotetext{
${ }^{9}$ Nils Gilman, Mandarins of the Future (Baltimore: Johns Hopkins University Press, 2007), p. 18.

${ }^{10}$ Stephen Hopgood, The Endtimes of Human Rights (Ithaca, MY: Cornell University Press, 2013), pp. 98-102.
} 
This is the Accepted Version of an article published online 28 June 2016 by Oxford University Press in London Review of International Law. Please refer to published version when citing, available at:

http://Iril.oxfordjournals.org/content/early/2016/06/27//ril.Irw011.extract

Accepted Version Downloaded from SOAS Research Online: http://eprints.soas.ac.uk/22669/

markets, and state and corporate research and development, whether for medicine, energy, transport, weapons or retail, meant increasing specialization and with it the impossibility of mere mortals understanding let alone contesting complex economic or scientific claims. The days when an amateur could change an engine or even fix a phone are long gone. And underwriting all of this was the law, particularly regulatory law. This rapidly growing branch of legal work was essential to create and regulate business affairs once welfare states divested themselves of control over key public utilities and natural monopolies, and as new technology and financial innovation created vast new and hugely complicated global markets. ${ }^{11}$ Law was now a mechanism for distributing resources through apportioning rights to economic spoils, granting and denying access to markets and protecting profits and R\&D, and creating (and barring) access to political power (think Citizens United). In the sphere of war, law had long regulated conflict, setting limits to (but creating opportunities for) state power. Now lawyers became an ever-present part of battlefield decisions, the growth of conventional and customary law creating, as it were, specific markets for legitimate killing. Generally, legalization spawned a vast industry of rules and their privileged and credentialed legal interpreters, all taking a slice. The worlds of law and economics interacted and overlapped and risk became the dominant lens, the value of a law less now about whether it was right or wrong and more about the possible costs and benefits of its implementation. Which brings us to $A$ World of Struggle.

Kennedy's argument is wide-ranging in its implications but straight-forward in its conception:

Expertise is special knowledge made real as authority in struggle. My starting point for exploring expertise is the work experts do rather than the specialized knowledge they bring to bear. Expertise is less a form of knowledge deployed by specialized actors than a form of knowledge work undertaken by all kinds of people in their relationship with others. Expert work positions the people who do it between what is known and what must happen. The work is interpretive, translating the known

\footnotetext{
${ }^{11}$ Steven Kent Vogel, Freer Markets, More Rules: Regulatory Reform in Advanced Industrial Countries (Ithaca, NY: Cornell University Press, 1998).
} 
This is the Accepted Version of an article published online 28 June 2016 by Oxford University Press in London Review of International Law. Please refer to published version when citing, available at:

http://Iril.oxfordjournals.org/content/early/2016/06/27/Iril.Irw011.extract

Accepted Version Downloaded from SOAS Research Online: http://eprints.soas.ac.uk/22669/

into action and knitting the exercise of power back into the fabric of fact. One characteristic of this work is disagreement. Experts struggle with one another using tools of interpretation, articulation, and persuasion that are, when effective, at once words and authority (p. 108).

We may be in the hands of these experts but the result of that, argues Kennedy, is both undesirable and depressingly durable.

The global political and economic arrangements that result are surprisingly sturdy for all the talk of crisis and worry over sustainability. Terribly unjust, subject to crisis, environmentally unwise, everywhere politically and economically captured by the few, and yet somehow impossible for anyone to alter or escape. My hypothesis is that this stability arises from the relative invisibility and imperviousness of the world of technical management to contestation ( pp. 31-32).

Why is the great game of expert contest so impervious to change? Why do we not storm this bastille, sluice out the executive meeting rooms and expose the rule of experts to the cold light of transparency? Is this because we are not a 'we' and are unlikely to become one, remaining a 'multitude' lacking enough strategic cohesion and vision to clamber up the mountain together to Davos? ${ }^{12}$ This is not Kennedy's answer. For him, we have lost track of how to challenge the negative effects of our world of endless expert policy-making other than in the language of more expertise. We are inside The Matrix. ${ }^{13}$ If we are to fight back we need champions who are experts too or we'll never escape the cage. In effect, someone needs to call us a good lawyer. We can only challenge law with more law, policy with more policy, economic analysis with economic analysis. Kennedy describes this vividly:

A great deal would need to change to turn all this around. In some way, insiders and outsiders are speaking the same language, inhabiting opposing roles in a common

\footnotetext{
${ }^{12}$ Michael Hardt and Antonio Negri, Multitude: War and Democracy in the Age of Empire (London: Penguin, 2005).

${ }^{13}$ The Matrix, Written and Directed by the Wachowski Brothers (Warner Bros., 1999).
} 
This is the Accepted Version of an article published online 28 June 2016 by Oxford University Press in London Review of International Law. Please refer to published version when citing, available at:

http://Iril.oxfordjournals.org/content/early/2016/06/27/Iril.Irw011.extract

Accepted Version Downloaded from SOAS Research Online: http://eprints.soas.ac.uk/22669/

theater. From both perspectives, the ways power operates across the world remain obscure. The missing piece, l've come to believe, is the way expert ideas and professional practices of assertion and argument construct and reproduce a world of inequality and injustice. In world affairs, expertise is the coin of the realm. Whether you occupy the commanding heights or have occupied Wall Street, the work of routine reform and resistance will be carried out as a practice of expertise (p. 14).

There is much that's intuitively persuasive about this analysis. In the fields Kennedy chooses, economic policy and international law, it can be hard to grasp the ethical centre at all. Nothing better illustrates this than international humanitarian law, where all that separates the ICRC and military lawyers are often who wears a suit and who a uniform while they discuss who can be killed and with what sort of gruesome weapon - exploding bullets are out, flame throwers are in. Rather than objecting on principle to the whole business of burning someone alive, this becomes a technical analysis of which sorts of horrific death do or do not accord with the law. They use the law to draw the parameters of the market for death. As Kennedy says, 'War and law have teamed up to divorce politics from ethical choice and responsibility while structuring and defending a global political or economic order of ongoing and unequal struggle...Working in partnership, modern law and modern war have enforced and pacified the boundaries of today's global architecture, while erasing their complicity and partnership with power and evading both ethical and political responsibility' (p. 276).

This represents evidence, for Kennedy, of the empty heart of much international legal analysis. No-one asks about the law's validity anymore, only about how a particular law or analysis can be yoked to realise a specific goal. In the past international lawyers would argue about whether the validity of law lay in its natural, that is moral, claims or in the fact that it simply was the law as agreed to by some mechanism previously accepted as a marker of that law's validity. But, 'An international law professional today ought to be an eclectic and savvy strategist, drawing on all these theories and their progeny. The question to which these theories respond-what makes law binding as law-remains central to expert 
This is the Accepted Version of an article published online 28 June 2016 by Oxford University Press in London Review of International Law. Please refer to published version when citing, available at:

http://Iril.oxfordjournals.org/content/early/2016/06/27//ril.Irw011.extract

Accepted Version Downloaded from SOAS Research Online: http://eprints.soas.ac.uk/22669/

practice, in the sense that one should have lots to say about it, but it is also important to realize that there is no clear answer and it would seem professionally naive to expect there to be' (p. 156). The result is often 'lawfare,' a concept Kennedy has been prominent in popularizing, where finding a convenient legal interpretation to allow (or prevent) some form of state action becomes as much a part of military strategy as battlefield tactics. Even President Obama has been adept at this as a Harvard-trained lawyer once taught by Kennedy himself. ${ }^{14}$

Part of this transformation is what we might call the divorce of word from world, the defining characteristic of our era's constructivist episteme in which it isn't clear that anything is anchored in the 'real' or 'natural' worlds, moral or empirical, at all. It's all just talk (or rather it's all just discourse, to talk being to act). We live in a world of social institutions, linguistically made, constructed and sustained by recognition in use. The idea of the foundational validity of the law is a casualty of this.

Ultimately...an international legal argument is just an argument; an enforcement action just an exercise of power. International legal theory is just a collection of arguments you can try in discussion with a skeptic, none of them watertight. What makes international law a sophisticated and disenchanted profession is the shared realization that this is the case and a determination to forge ahead. As a result, international law is best understood not as a philosophical mystery to be solved, but as a profession: the work of people who animate the practices, norms, and ideas that have been gathered in its name. What holds the field together is a professional identity that is part shared faith in international law's usefulness and long-term potential, part practice of fealty and strategic engagement on behalf of that faith, and part shared sensibility or posture aligning these ethical commitments and pragmatic strategies (p. 242).

We return to disenchantment and faith shortly. First, let us note that in this modern legal

\footnotetext{
${ }^{14}$ Jo Becker and Scott Shane, 'Secret 'kill list' proves a test of Obama's principles and will,' International New York Times, May 29, 2012.
} 
This is the Accepted Version of an article published online 28 June 2016 by Oxford University Press in London Review of International Law. Please refer to published version when citing, available at:

http://Iril.oxfordjournals.org/content/early/2016/06/27//ril.Irw011.extract

Accepted Version Downloaded from SOAS Research Online: http://eprints.soas.ac.uk/22669/

disenchantment we see how the dilemmas Weber outlines begin to bite hard. If it is, as Kennedy argues, one argument (one legal opinion) against another, then the question 'which of us is right' is the wrong one to ask. What matters is who wins. We prize experts for their facility in helping us get what we want. There is no place for the why question, the what's it all for question. Every expert intervention is just a move in the great 'war of position' as Gramsci might have put it. It matters less whether something is true than that it can be made to seem true, whether we are talking about climate change, the negative effects of smoking or the causes of gun violence. Therein lies the difference between facts and social facts, the latter only true to the extent that they are treated as true.

It is important to bear in mind here something that Kennedy at times glosses. While we may be sceptical about all claims to universal, objective, impartial knowledge, the capacity (as in having the requisite characteristics) to make such claims - to stake out the moral or scientific high-ground - is an important part of the struggle. And only some can successfully do it. In my own work I have argued that we should understand Amnesty International as an elaborately organised way to do precisely this, establish the foundations for a claim that there is universal moral knowledge available to intuition, one singular, true answer to questions about what is right and wrong. ${ }^{15}$ Not everyone can successfully make an attempt to substantiate this claim because they lack the preconditions for claiming universal authority. This introduces a diversity, even a hierarchy, into kinds of expertise and forms of knowledge which Kennedy can at times overlook because he focuses on experts as a general category more than on specific kinds of expertise.

This leads to a further reservation about specific expertise. Can claims made by scientific experts (about antibiotic resistance or the properties of graphite or drug treatments for cancer) be as easily rejected as those made by lawyers? Some forms of expertise and expert have more convincing forms of knowledge in their backpacks (a favourite Kennedy metaphor) than others. You can always get another legal opinion and while you can always get another scientific opinion (think quantum mechanics), the barrier to being taken

\footnotetext{
${ }^{15}$ Stephen Hopgood, Keepers of the Flame: Understanding Amnesty International (Ithaca, NY: Cornell University Press, 2006).
} 
This is the Accepted Version of an article published online 28 June 2016 by Oxford University Press in London Review of International Law. Please refer to published version when citing, available at:

http://Iril.oxfordjournals.org/content/early/2016/06/27//ril.Irw011.extract

Accepted Version Downloaded from SOAS Research Online: http://eprints.soas.ac.uk/22669/

seriously is significantly higher. The germ theory of disease prevailed in the end as did antismoking advocates whose lawyers used expert scientific evidence to win out against the lawyers on the other side. In an analogous way, the cautionary tale of the medical technology company Theranos reminds us that most savvy investors with biotech PhDs on their boards wouldn't touch the company with a barge pole because there was 'so much hand waving' and not enough hard data and scientific expertise. ${ }^{16}$ Some professions have a higher bullshit threshold than others. Thus Kennedy's argument might say more about lawyers, and perhaps lawyers in the United States, than about expertise per se.

Looking at science or medicine certainly presents a more upbeat view of modernity's possibilities: that the capacity for rational communication and collective endeavour holds some promise that 'we,' whoever 'we' are, might work out a path forward together. Otherwise, we are trapped within a soulless game of winning and losing, of billable hours and the self-aggrandizing pursuit of cultural capital. It becomes a sport where instrumental skill is prized. This was Weber's prediction for acquisitive Protestant culture once it lost touch with the signs of grace that had been the point of showing self-restraint and asceticism in the first place. Capitalism was now loosed from its moorings.

...the idea of duty in one's calling prowls about in our lives like the ghost of dead religious beliefs. Where the fulfilment of the calling cannot directly be related to the highest spiritual and cultural values, or when, on the other hand, it need not be felt simply as economic compulsion, the individual generally abandons the attempt to justify it at all. In the field of its highest development, in the United States, the pursuit of wealth, stripped of its religious and ethical meaning, tends to become associated with purely mundane passions, which often actually give it the character of sport. ${ }^{17}$

If there is no shared purpose, and experts are trapped into this disenchanted but highfunctioning sporting contest marked by instrumentalism and competition - what we might

\footnotetext{
${ }^{16}$ Randall Stross, 'Don't blame Silicon Valley for Theranos,' New York Times, April 272016.

${ }^{17}$ Max Weber, The Protestant Ethic and the Spirit of Capitalism (London: Routledge Classics, 2001), p. 124.
} 
This is the Accepted Version of an article published online 28 June 2016 by Oxford University Press in London Review of International Law. Please refer to published version when citing, available at:

http://Iril.oxfordjournals.org/content/early/2016/06/27//ril.Irw011.extract

Accepted Version Downloaded from SOAS Research Online: http://eprints.soas.ac.uk/22669/

call the Goldman/McKinsey/DLA Piper view of the world, where time is money, and everything is business - how might expectant and principled young lawyers rescue themselves? One answer could be to forsake private practice for public, international and human rights law but this is far from immune, as Kennedy shows, from instrumentalism. Another might be to forsake government, for the iron logic of the state's need to prevail will ultimately catch you as will your candidate's need to up protect her poll numbers to get elected. But aren't the ICRC and the Pentagon both playing lawfare, just from opposite sides? Kennedy's answer lies in an attachment to the ethic of responsibility, expressed through its negation: 'The lost opportunity to engage expertise as a doorway to responsible decision rather than as a substitute for ethical reflection and political choice is dramatically on display in the increasing legalization of military conflict' (p. 13).

Responsibility can be exercised, in other words, within the game. There are better and worse decisions, from an ethical point of view. Take lawfare, for example. Jack Goldsmith, a conservative lawyer appointed as head of the Justice Department's Office of Legal Counsel (OLC) in 2003 under President George W Bush, was faced on taking office with legal opinions that supported what President Obama and Congress would later openly call torture:

As I absorbed the opinions, I concluded that some were deeply flawed: sloppily reasoned, overbroad, and incautious is asserting extraordinary constitutional authorities on behalf of the President. I was astonished, and immensely worried, to discover that some of our most important counterterrorism policies rested on severely damaged legal foundations. It began to dawn on me that I could not - as I thought I would eventually be asked to do - stand by or reaffirm these opinions. ${ }^{18}$

On the face of it, this looks like the existence of a moral limit to the interpretation of the law. And yet, as Goldsmith goes on to say in explaining why he did not resign, he decided to

\footnotetext{
${ }^{18}$ Jack Goldsmith, The Terror Presidency: Law and Judgment Inside the Bush Administration (New York: W. W. Norton and Co, 2009), p. 10.
} 
This is the Accepted Version of an article published online 28 June 2016 by Oxford University Press in London Review of International Law. Please refer to published version when citing, available at:

http://Iril.oxfordjournals.org/content/early/2016/06/27/Iril.Irw011.extract

Accepted Version Downloaded from SOAS Research Online: http://eprints.soas.ac.uk/22669/

'try to fix the opinions that a sound legal analysis would support. ${ }^{19} \mathrm{~A}$ 'sound legal analysis'? This could mean that the opinions were just bad law in that they were poorly anchored in their sources and thus of dubious validity. This implies that if a better anchored legal opinion had been possible it might then have better justified so-called 'enhanced interrogation techniques.' Or it could mean that legal opinions sanctioning waterboarding were in fact justification for illegal actions that broke both the Geneva Conventions and American domestic law and could never be accepted as binding law. In any event, Goldsmith, for one of these reasons, did what one assumes Kennedy would say was the 'responsible' thing and retracted the offending opinions (all under the watchful eyes of a portrait of Attorney General Elliot Richardson who defied Richard Nixon's demand to fire Watergate special prosecutor Archibald Cox). But if, in the process, the principle of torture was not repudiated then the main charge is bad lawyering - a failure of expertise - not a moral failure as Congress would later allege in its Torture Report.

Responsibility is one, slim hope. Aren't there also political limits to the creativity of expert lawyers? Kennedy at times sees everyone as an expert, even politicians.

It would be better to imagine expert "deciders" and expert "advisors" in dialog with one another, their positions marked by their use of different fields of knowledge or different styles of argument. The advisor might, for example, speak the language of development policy, the leader a language of political ideology or interest (p. 137).

But here we confront questions of power that the focus on experts elides. Kennedy's view of the relationship between power and expertise is captured in the following observation: 'Precisely because it is a two-way street-my ideas legitimate your power, your power enforces my ideas - the exercise of power, even as brute force, occurs within a discursive world of meaning. Ideas, ideologies, and myths are able to legitimate only when they are hegemonic across people with the power to halt or support that exercise of power. Understood in this way, the operations of power are expertise all around' (p. 9). But this

${ }^{19}$ Goldsmith, The Terror Presidency, p. 11. 
This is the Accepted Version of an article published online 28 June 2016 by Oxford University Press in London Review of International Law. Please refer to published version when citing, available at:

http://Iril.oxfordjournals.org/content/early/2016/06/27//ril.Irw011.extract

Accepted Version Downloaded from SOAS Research Online: http://eprints.soas.ac.uk/22669/

clouds the issue.

State bureaucrats, prima facie have the resources to prevail, often and predictably, whether through money, law, other arms of the state, special access to the media, to important strategic information and to justificatory rhetorical claims like 'the national interest.' However genuinely engaged in a conversation about drug policy or counterterrorism they might be, in the end they will have a decision to make, or to recommend, and one that will involve political as well as scientific calculations (a decision that will not necessarily come down to the best possible public interest argument). They are super-ordinary experts, in other words, experts with an extra dose of juice. Some experts are more equal than others regardless of how well they play the game.

Above them, of course, sit decision-makers. These people too can sound like experts in Kennedy's rendering but they're really not: elected politicians (or monarchs and autocrats), corporate titans and fabulously wealthy individuals and families, all play a significant, even determining, role in Kennedy's 'struggle' but none is really caught by the loosely thrown net of expertise. They may act based on gut instinct, rank prejudice, flawed reasoning, passion and perhaps most importantly of all naked self-interest and unfettered desire. There is the hint of redemptive potential in the sense that something remains pure about the idea of the expert, cleaving to her analysis of the best way to argue a particular problem in law, or to protect the profits of her clients, but not morally tarnished in her soul. She doesn't own the capital and she is only following orders. It is her boss who makes the call. To quote Margaret Thatcher: 'Don't tell me what, I know what. Tell me how. ${ }^{\prime 20}$ In other words, use your skills to get me what I want: more power, more influence, more money, a bigger market, a won war, world domination.

The current shock and horror about one of the world's oldest professions, tax lawyers, helping wealthy clients hide cash from the prying eyes of states helps to re-emphasize just how important the law is to greasing just this one small aspect of the world's arterial system

\footnotetext{
${ }^{20}$ John Campbell, Margaret Thatcher, Volume 1: The Grocer's Daughter (London: Vintage Books, 2007), p. 366. Italics in original.
} 
This is the Accepted Version of an article published online 28 June 2016 by Oxford University Press in London Review of International Law. Please refer to published version when citing, available at:

http://Iril.oxfordjournals.org/content/early/2016/06/27//ril.Irw011.extract

Accepted Version Downloaded from SOAS Research Online: http://eprints.soas.ac.uk/22669/

of rich people's money. There is a political economy beyond expertise that patterns real world outcomes in consistent and predictable ways, in other words. Which experts win, whether in court cases, over tax liabilities, or in terms of facilitating the state's security projects, is far less open to competition than Kennedy's picture might suggest. As Americans wake up to stagnant real wages for the middle class and a rising share of wealth for the $1 \%$ and their children and their children's children they have begun to work out what any Marxist would have told them decades ago - that the game is rigged, as support for antiestablishment candidates like Donald Trump and Bernie Sanders suggests, and that experts, for which read lawyers, bankers and management consultants, are the shock troops.

Which brings us to the strongest argument against Kennedy's thesis - that his never-ending struggle is ending, not in the victory for one set of experts over others but in a repudiation by the demos at large of the rule of elite experts in its entirety. As Peter Finch's character Howard Beale so indelibly puts it in Network: 'I'm as mad as hell and I'm not going to take this anymore.' There are protest candidates from the right concerned about the erosion of national communities and traditional values, protest candidates from the left who worry about lost jobs and the unaccountable decisions of central bankers and the scions of Wall Street, protest candidates from the centre who bemoan the devastation of the environment and the curtailment of civil liberties. In almost all mature democracies, increasing numbers of voters call themselves independents while assertive social protest movements mobilize in ever greater numbers on issues like immigration, corruption and economic inequality.

There has always been a tension between experts and the people. The problem of democracy, for an expert elite, was what to do when the people wouldn't listen to reason. Modernization theorists feared the 'irrational demos' as, in foreign policy terms, realist did too. The neocons might be advocates for democracy but they have a healthy Strauss-like respect for elite rule. Experts in this world of governance have worked for decades within a context (Kennedy's word), that gives them unrivaled access to power and authority in making a whole series of public policy decisions on the basis of legal-rational criteria. This context is comprised by the sedimented background assumptions that are now orthodoxy, 
This is the Accepted Version of an article published online 28 June 2016 by Oxford University Press in London Review of International Law. Please refer to published version when citing, available at:

http://Iril.oxfordjournals.org/content/early/2016/06/27//ril.Irw011.extract

Accepted Version Downloaded from SOAS Research Online: http://eprints.soas.ac.uk/22669/

received opinion, the world of natural facts and common-sense that provides an outer frame to everyday expert competition. These assumptions have been challenged - on gender, class, race, morality, sexuality, justice, freedom - as long as there have been experts to interpret and defend settled opinion. What l'm suggesting is that the pendulum might be shifting towards more radical change. Why do we incarcerate so many people, should drugs be legalized, are the police racist, is the state patriarchal, why is there persistent structural inequality, why can't refugees expect sanctuary in other states, how will we save the climate, why are we fighting an endless war? These questions, often asked, have now got people mobilized. The contours of expertise will be forced to shift as a result. We are trapped no longer within the set of normative structures which make it hard to unthink what we know and think something different. When the dust settles, new experts might arise. But their context will be very different and maybe their outlook will be too. Or perhaps it will be a world of radical democracy, of more anarchy, one where devolved networks of governance and consensus-making proliferate, a world in which it is the demos that speaks and acts according to its own collective analysis of what's required.

This shift could be revolutionary. It will not (necessarily) be progressive of course, and it may represent very different currents of change than Weber's vision of modernity. Revitalized religious intensity and the rise of the Evangelical Christianity, Charismatic Catholicism, Hindutva, the Muslim Brotherhood, Al Qaeda and the Islamic State are just as much radical responses to 'business as usual' (that is, a world run by secularized Western expert elites). These new prophets are waging a different struggle and are taking things out of the hands of Kennedy's experts entirely. Concerns about the overly professionalized and corporatized world of global human rights and humanitarianism are further examples of an awareness that the rule of experts is threatened. One recent report on humanitarianism's future was titled Time to Let Go. ${ }^{21}$ This might be an epitaph for expert rule.

It's unlikely, of course, that any embedded expert is going to go so quietly. Identified with the maintenance of the ancien regime, they have more to lose by throwing in their lot with

\footnotetext{
${ }^{21}$ Overseas Development Institute/Humanitarian Policy Group, Time to Let Go: Remaking Humanitarian Action for the Modern Era (London: ODI, 2016).
} 
This is the Accepted Version of an article published online 28 June 2016 by Oxford University Press in London Review of International Law. Please refer to published version when citing, available at:

http://Iril.oxfordjournals.org/content/early/2016/06/27//ril.Irw011.extract

Accepted Version Downloaded from SOAS Research Online: http://eprints.soas.ac.uk/22669/

the revolutionaries as by ganging together with the established powers and defending their interests. They might tough it out even in the face of the overwhelming feeling that Beale articulates so poignantly in Network: That the powers that be, the experts, are not listening to us. In the end 'the people' simply is sovereign in any but the most totalitarian system; collective action problems aside, there are just so many of them (or us).

Because the law is really politics this is a fitting result, a lifting of the veil, a sudden moment of clarity like Mohamed Bouazizi's self-immolation. As Kennedy puts it: 'Although experts routinely imagine their work as a technical and pragmatic practice at least aspirationally removed from conflict and political contestation, the idea that "politics" is somehow different is its own kind of expert fantasy' (p. 3). The end of this fantasy means the return of the political, a direct confrontation between the holders of power and those who seek to make it more genuinely accountable. In this existential slow-motion clash, if it comes, experts will be like fleeing tax lawyers looking for a haven of their own. How will they understand the rage?

Kennedy acknowledges that, 'The modern international legal profession is a case study of sophistication through disenchantment.' (p. 220). They rule but they do not enjoy it. In his introduction, he notes Unger's description of modern experts as a 'priesthood that had lost their faith and kept their jobs,' standing in 'tedious embarrassment before cold altars. ${ }^{, 22} \mathrm{~A}$ World of Struggle is a dialogue with this grim conclusion from one of Kennedy's esteemed forerunners. We are back with Weber on the protestant ethic as sport, his famous description of those caught in the cycle of competition without recourse to foundational values as 'specialists without spirit, sensualists without heart; this nullity imagines that it has attained a level of civilization never before achieved. ${ }^{23}$ Is this where modern lawyers are? Even human rights and humanitarian lawyers? Kennedy sees legal experts as having lost their ethical centre while at the same time retaining an unarticulated faith in their own rectitude (despite their often instrumental cynicism). He channels Weber:

\footnotetext{
${ }^{22}$ Roberto Unger, 'The Critical Legal Studies Movement,' 96 Harvard Law Review 561, pp. 674-76 (1983), as quoted in Kennedy, A World of Struggle, p. 20.

${ }^{23}$ Weber, The Protestant Ethic, p. 124.
} 
This is the Accepted Version of an article published online 28 June 2016 by Oxford University Press in London Review of International Law. Please refer to published version when citing, available at:

International lawyers can hardly avoid coming face-to- face with the diversity and analytic porousness of their expertise. Such an experience of legal pluralism might open the way to exploring law's role in distributive conflict and the responsibility of legal experts for the outcomes of struggle. By and large, however, this has not happened. Instead, international lawyers have transformed pluralism into another tool for technical managers, bypassing its radical potential. The fragmentation and pluralization of the field have focused the attention of experts forward on the future world-ordering potential of law and the prefigurative quality of its current institutional expressions without noticing its implication in contemporary dysfunction and injustice. The attitude that results, at once ethically confident and practically disenchanted, is inhabited in a way reminiscent of sensibilities for accommodating both belief and doubt within a practice of faith in Protestant religious traditions with which I am familiar (pp. 12-13).

'To ask how hegemony arises is to participate in its erosion,' says Kennedy (p. 37). One is tempted to respond that turkeys do not vote for Thanksgiving. The revolution is more likely to begin with the involuntary removal of the lawyers, a common populist cry. It will not be enough to shout 'but I'm a human rights lawyer' as the crowd carries you away. Getting lawyers, academics, economists, scientists, to see their - our - own complicity in a world drifting deeper into ecological and social crisis might be a start. Some of us may be saved. $A$ World of Struggle is a call to set out on that journey, not in the language of condemnation but in Kennedy's self-reflective, agonized, even Stoic company. He is, after all, an expert too. 